\title{
Pendampingan Kelompok Usaha Kerupuk Rajungan Sebagai Upaya Pemberdayaan Masyarakat Di Kawasan Pesisir Pantai Utara Cirebon
}

\author{
Ria Adriyani ${ }^{1 *}$, Erna $^{2}$, Agus Siswanto ${ }^{3}$, Rachmat Indrianto ${ }^{4}$ \\ Universitas 17 Agustus 1945 Cirebon \\ 1 e-mail: ria.adriyani@untagcirebon.ac.id \\ 2 e-mail: erna@untagcirebon.ac.id \\ ${ }^{3}$ e-mail: asiswanto@untagcirebon.ic.id \\ ${ }^{4}$ e-mail: indrianto_72@yahoo.co.id \\ *Corresponding Author
}

\begin{abstract}
ABSTRAK
Masyarakat Desa Citemu yang berada di pesisir pantai utara Kabupaten Cirebon kehidupannya tergolong rentan secara sosial ekonomi karena tidak memiliki penghasilan yang tetap, mayoritas sebagai nelayan dengan penghasilan tidak menentu. Persoalan sulitnya memperoleh penghasilan bagi keluarga nelayan menjadi pemikiran pengabdian masyarakat bagaimana menggali potensi yang ada di wilayah tersebut agar masyarakat memiliki sumber penghasilan tambahan. Program pemberdayaan masyarakat ini dilaksanakan dengan skema pemberdayaan (1) membentuk kelompok usaha kecil yang memanfaatkan sampingan olahan hasil laut berupa telur atau lemi rajungan sebagai bahan baku produk usaha kecil kerupuk rajungan,(2) merintis usaha secara berkelompok dan bekerjasama dalam kelompok usaha kecil (3) memproduksi kerupuk dalam skala kecil / industri rumahan (4) membuat kerupuk yang berkualitas baik sehingga memiliki nilai jual (5) dipasarkan kepada konsumen sehingga memberikan penghasilan bagi masyarakat. Pemberdayaan masyarakat dengan metode pendampingan yang menjadi (1) fasilitator, (2) komunikator, (3) motivator dan (4) dinamisator. Berkat pendampingan kepada kelompok usaha para perempuan yang dilaksanakan melalui program pemberdayaan masyarakat ternyata berhasil memberi semangat dan dorongan yang positif, terbentuk kelompok masyarakat para ibu yang membuat cemilan khas daerah pesisir berupa kerupuk rajungan. Keberhasilan program ini adalah masyarakat mampu menjalankan usaha kerupuk rajungan secara mandiri dan berproduksi secara kontinu sehingga masyarakat bisa memiliki usaha kecil serta memperoleh income generic.
\end{abstract}

Kata Kunci: Pemberdayaan Masyarakat, Pendampingan, Kerupuk rajungan

\begin{abstract}
Citemu Village on the north coast of the Cirebon Regency have a socio economic vulnerability because they do not have a steady income, the majority are fishermen with uncertain income. The problem of the difficulty of obtaining income for fishermen's family is the community service thinking is how to explore the potential that exists in the area to have additional sources of income. Empowerment program with scheme (1) forming small business groups that utilize by-products processed sea products in the form of eggs or small crab curry as raw material for small crab cracker business products, (2) starting businesses and cooperating in small business groups (3) producing crackers on home industry (4) making crackers of good quality (5) marketed to provide income for the community.Mentoring method who became (1) facilitator, (2) communicator, (3) motivator, (4) dynamic actor. Thanks to the assistance to the women's business group which was carried out through the community empowerment program, it turned out that they were able to provide positive. The success is that the community is able to run a small crab cracker business independently and produce continuously so that the community can have small business and earn generic income.
\end{abstract}

Keywords: Community Empowerment, Assistance, Rajungan Crackers, Income Generic 


\section{PENDAHULUAN}

Masyarakat nelayan di desa pesisir pantai umumnya memiliki kehidupan yang rentan dari sektor sosial ekonomi, secara kultural sikap kelompok masyarakat nelayan ini dipengaruhi oleh gaya hidup, kebiasaan hidup dan sikap budayanya (apatis, pasrah, kurang motivasi). Situasi yang menjadi keprihatinan, nampak ketidakberdayaan/ ketidakmampuan masyarakat di desa pesisir pantai ini meliputi ketidakberdayaan memenuhi kebutuhan-kebutuhan dasar seperti pangan dan gizi, sandang, papan, pendidikan dan kesehatan, khususnya ketidakmampuan melakukan kegiatan usaha produktif, serta ketidakberdayaan menjangkau akses sumberdaya sosial dan ekonomi. Salah satu desa di pesisir pantai utara Kabupaten Cirebon adalah Desa Citemu yang berpenduduk \pm 3.819 Jiwa dan Luas Wilayah 167,764 Ha, dimana 60\% berupa daratan pesisir pantai dan 40\% daratan dimanfaatkan sebagai lahan pertanian dan untuk perkebunan. Desa Citemu terdiri dari 3 Dusun, 3 RW dan 9 RT. Di Desa Citemu mata pencaharian utama masyarakatnya yaitu 81,98\% sebagai nelayan. tercatat sebanyak 1.952 jiwa. 5,16\% sebagai pedagang, $10 \%$ sebagai buruh/ swasta, $10.49 \%$ petani 1,93, dan PNS 0,42 \%. Desa Citemu mempunyai jumlah penduduk 3.926 jiwa dan 1.055 KK. Dari sisi potensi dan karakteristik Desa Citemu, terdapat permasalahan umum yang dihadapi masyarakat Desa Citemu, antara lain:

1. Adanya peningkatan suhu udara baik di darat maupun di laut.

2. Tingginya abrasi dan akresi di sepanjang pantai dan wilayah pesisir

3. KK miskin masih cukup banyak

4. Minimnya tanaman mangrove sebagai sabuk hijau

5. Sering terjadi gelombang tinggi atau Rob sehingga menimbulkan banjir.

6. Kurangnya sarana air bersih

7. Pendangkalan muara sungai sebagai akibat tingginya tingkat sedimentasi, sehingga menyulitkan masyarakat untuk melaut.

8. Lokasi penangkapan ikan yang semakin jauh mengakibatkan semakin berkurangnya hasil tangkapan di daerah tangkapan sebelumnya.

9. Musim gelombang kuat (musim barat) terasa lebih lama dari biasanya, sehingga menyulitkan nelayan untuk kembali melaut.

10. Masih kurangnya kesadaran masyarakat akan kebersihan lingkungan.

11. Masih banyaknya drainase yang mampet / tidak berfungsi dengan baik.

12. Belum tertatanya lingkungan pemukiman dengan baik

13. Masih ada rumah tak layak huni. 
Kondisi masyarakat Desa Citemu walaupun wilayahnya berada dekat dengan perkotaan ternyata memiliki keterbatasan kualitas sumberdaya manusia, menyebabkan kehidupan mayarakat jauh dari kehidupan layak, hal ini tentu cukup memprihatinkan seperti dikemukakan (Albar \& Yonaldi, 2013) permasalahan kemiskinan di perkotaan membuat ketebatasan pemerintah didalam memenuhi sarana dan prasarana, kurangnya kesempatan kerja, dan rendahnya pendapatan pendukuk sebagai akibat dari meningkatnya jumlah pengangguran menjadi awal meningkatnya angka kemiskinan di perkotaan. Untuk mengatasi keadaan ini pemerintah melakukan berbagai macam usaha-usaha pemberdayaan manusia agar terbebas dari kemiskinan,

Sesungguhnya masyarakat pesisir pantai memiliki potensi untuk berwirausaha seperti halnya masyarakat di Desa Citemu Kecamatan Mundu pesisir Kabupaten Cirebon. Mereka membutuhkan pendampingan bagaimana mengembangan produk khas daerah pesisir misalnya kerupuk rajungan sebagai produk usaha kecil dalam upaya meningkatkan kesejahteraan masyarakat. Sependapat dengan (Dahuri, Irianto, \& Arovah, 2004) yang menyebutkan bahwa pengolahan ikan disamping pengasinan ikan interaksi yang terjadi antara usaha penangkapan ikan dan penguasan teknologi menyebabkan munculnya alternatif mata pencaharian baru di pesisir Cirebon berupa pengolahan hasil laut seperti pembuatan terasi, udang beku, pindang, kerupuk, kerupuk kulit ikan, dan pengawetan ebi.

Berdasarkan hasil observasi ada peluang besar untuk mengusahakan pemberdayaan masyarakat desa Citemu pesisir pantai utara berbasis produk-produk yang memanfaatkan sampingan olahan hasil laut, dengan terlebih dahulu menginventarisir situasi, kondisi, maupun potensi yang dihadapi kelompok masyarakat Desa Citemu dengan cara :

1. Membentuk kelompok usaha kecil beranggotakan beberapa orang untuk bersedia memproduksi kerupuk secara bersama.

2. Memanfaatkan telur dan lemak rajungan yang tidak memiliki nilai jual menjadi bahan dasar kerupuk rajungan.

3. Membantu kelompok masyarakat mencari info dan metode/cara pengolahan kerupuk yang bisa menghasilkan kerupuk berkualitas baik dan rasa yang enak.

Kegiatan pemberdayaan merupakan hal yang jika dilaksanakan secara terstruktur dan mendapat respon positif dari masyarakat mampu memiliki tingkat keberhasilan yang berpotensi untuk meningkatkan kesejahteraan masyarakat seperti contoh produktivitas masyarakat di desa penghasil mangga (Adriyani, 2019). Pendampingan dilaksanakan terhadap masyarakat desa Gumulung yaitu memberdayakan kelompok ibu-ibu dalam kegiatan pelatihan produksi, kemasan hingga pemasaran, Proses pembuatan produk manisan mangga dibantu mentor yang berpengalaman membuat manisan mangga. Upaya memanfaatkan mangga yang semula akan 
terbuang atau tidak mempunyai nilai ekonomi justru menjadi sumber penghasilan tambahan yang menguntungkan, berpotensi meningkatkan kesejahteraan masyarakat.

Upaya pemberdayaan terhadap masyarakat pesisir pantai utara sejalan juga dengan upaya program-program pemberdayaan di lingkungan masyarakat khususnya para perani garam telah dilakukan oleh pemerintah melalui implementasi Program Usaha Garam Rakyat (PUGAR) seperti dikutip dari (Erna \& Adriyani, 2019) bahwa menciptakan iklim usaha masyarakat pesisir menjadi kreatif dengan pemberdayaan masyarakat, butuh campur tangan pemerintah agar masyarakat memiliki posisi tawar (bargaining position) melalui kebijakan real yang mampu melihat kondisi saat ini masyarakat petani garam sangat kekurangan modal kerja maupun investasi, juga ketiadaan alat pengolahan garam, agar garam yang produksi baik sesuai selera pasar,intinya adalah swasembada garam nasional. berdampak terhadap tingkat pendapatan para petani dan masyarakat sekitarnya

Hal yang demikian menunjukkan bahwa tingkat kesejahteraan masyarakat dapat diukur dari produktivitas usaha masyarakat itu sendiri, termasuk pengembangan potensi yang ada sehingga dapat memiliki penghasilan yang layak bagi keluarga.

\section{BAHAN DAN METODE}

Pemberdayaan masyarakat Desa Citemu pesisir pantai utara penting dilaksanakan untuk membantu mengatasi kesejahteraan bagi masyarakat, persoalan bagaimana melakukan pemberdayaan yang efektif agar masyarakat pesisir pantai dapat mengikuti program pemberdayaan, muncul dari gagasan pemberdayaan dan pemahaman tentang karakteristik sosial masyarakat pesisir sebagai kelompok yang akan diberdayakan. Aktivitas pemberdayaan ditengah masyarakat pesisir tentu membutuhkan strategi pemberdayaan masyarakat sebagai upaya yang dilakukan untuk meningkatkan kemampuan atau kapasitas masyarakat, bisa disebut juga dengan penguatan kapasitas (capacity building). Penguatan kapasitas ini merupakan suatu proses dalam pemberdayaan masyarakat dengan meningkatkan atau merubah pola perilaku individu, organisasi, dan sistem yang ada di masyarakat untuk mencapai tujuan yang diharapkan secara efektif dan efisien. Melalui penguatan kapasitas ini, maka masyarakat dapat memahami dan mengoptimalkan potensi yang mereka miliki untuk mencapai tujuan pemberdayaan, yaitu kesejahteraan hidup masyarakat. Salah satu upaya yang digunakan dalam penguatan kapasitas ini adalah melalui pendampingan. Strategi pendampingan dianggap efektif dan efisien dalam proses pemberdayaan masyarakat, karena dengan adanya pendampingan maka kapasitas masyarakat dapat dikembangkan atau diberdayakan untuk memenuhi kebutuhan hidup masyarakat, pada akhirnya dapat meningkatkan kesejahteraan hidup masyarakat dan secara tidak langsung dapat membantu 
pemerintah dalam mengurangi tingkat ketidakmapanan masyarakat. Menurut (Mulyadi, 2009), pemberdayaan adalah upaya yang dilakukan pemerintah, pemerintah daerah, dunia usaha dan masyarakat secara sinergis dalam bentuk penumbuhan iklim dan pengembangan usaha terhadap Usaha Mikro, Kecil dan Menengah sehingga mampu tumbuh dan berkembang menjadi usaha yang tangguh dan mandiri. Tujuan pemberdayaan usaha mikro, kecil dan menengah adalah :

1. Mewujudkan struktur perekonomian nasional yang seimbang, berkembang dan berkeadilan.

2. Menumbuhkan dan mengembangkan kemampuan usaha mikro kecil dan menengah menjadi usaha yang tangguh dan mandiri.

3. Meningkatkan peran usaha mikro, kecil, dan menengah dalam pembangunan daerah, penciptaan lapangan kerja, pemerataan pendapatan, pertumbuhan ekonomi, dan penegntasan rakyat dari kemiskinan.

Prinsip pemberdayaan usaha mikro, kecil, dan menengah meliputi ;

1. Penumbuhan kemandirian, kebersamaan, dan kewirausahaan usaha mikro, kecil, dan menengah untuk berkarya dengan prakarsa sendiri.

2. Perwujudan kebijakan publik yang transparan, akuntabel, dan berkeadilan,

3. Pengembangan usaha berbasis potensi daerah dan berorientasi pasar sesuai dengan kompetensi usaha mikro, kecil, dan menengah.

4. Peningkatan daya saing usaha mikro, kecil dan menengah dan penyelenggaraan perencanaan, pelaksanaan dan penegendalian secara terpadu.

Berkaitan antara kegiatan pengabdian masyarakat yang diimplementasikan berupa program pemberdayaan masyarakat, maka pemerintah dalam hal ini diwakili lembaga perguruan tinggi yang salah satu tridarmanya adalah pengabdian kepada masyarakat, mempunyai peranan sebagai fasilitator untuk membantu upaya pemberdayaan masyarakat secara langsung di lapangan khususnya di Desa Citemu. Peranan tim pengabdian masyarakat adalah mendorong semangat kepada masyarakat, sebisa mungkin menciptakan dan memelihara suasana yang selalu memunculkan ide-ide baru dan kreatif di masyarakat, terakhir mampu meningkatkan sumber daya manusia untuk membangkitkan pelaku ekonomi lokal yang selalu berpikir secara mandiri

Dalam upaya pemberdayaan masyarakat perlu adanya suatu strategi yang nantinya dapat meningkatkan kesejahteraan hidup masyarakat. Salah satu strategi yang umum dipakai dalam proses pemberdayaan masyarakat adalah pendampingan. Menurut (Sumodiningrat, 2009),

Pendampingan merupakan kegiatan yang diyakini mampu mendorong terjadinya pemberdayaan fakir miskin secara optimal. Perlunya pendampingan dilatarbelakangi oleh adanya kesenjangan pemahaman diantara pihak yang memberikan bantuan dengan sasaran penerima bantuan. Kesenjangan dapat disebabkan oleh berbagai perbedaan dan keterbatasan kondisi sosial, 
budaya dan ekonomi. Dalam melaksanakan tugasnya, para pendamping memposisikan dirinya sebagai perencana, pembimbing, pemberi informasi, motivator, penghubung, fasilitator, dan sekaligus evaluator.

Sebagai perwujudan pemberdayaan masyarakat di desa Citemu yang membentuk kelompok usaha pembuatan kerupuk rajungan maka dibutuhkan peran pendampingan yang secara signifikan berpengaruh terhadap minat masyarakat untuk melakukan kegiatan yang produktif, dalam (Siswanti, Muadi, \& Chawa, 2016).

Peran pendamping dalam upaya pemberdayaan melalui Program Pendampingan sosial merupakan suatu strategi yang sangat menentukan keberhasilan program pemberdayaan masyarakat. Sesuai dengan prinsip pekerjaan sosial, yakni membantu orang agar membantu dirinnya sendiri. Dalam konteks ini peranan pekerja sosial seringkali diwujudkan dalam kapasitasnya sebagai pendamping, bukan sebagai penyempuh atau pemecah masalah (problem solver) secara langsung

Berdasarkan metode yang ada, dalam pelaksanaan kegiatan pemberdayaan masyarakat biasa mengkombinasikan unsur potensi masyarakat, kelompok serta peranan pendamping sebagai metode pemberdayaan disesuaikan dengan situasi dan kondisi di lapangan. Skema pemberdayaan untuk kelompok masyarkat Desa Citemu dibuat seperti diagram dibawah ini :

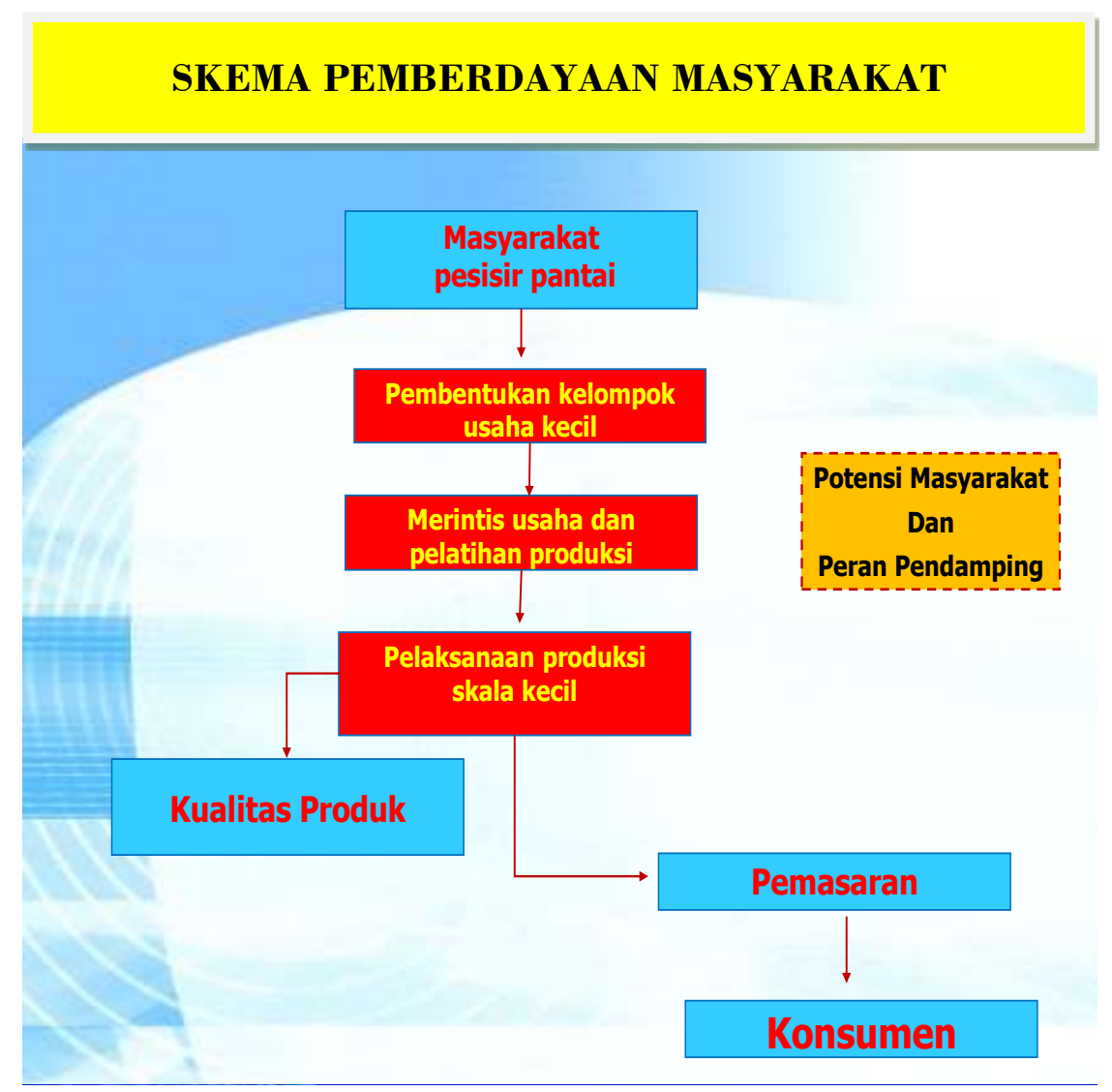

Sumber : (LPPM UNTAG Cirebon, 2015) 
Mengacu pada konsep pendampingan (Phinisi, 2009) bahwa pendampingan dapat dipahami sebagai kegiatan pemberdayaan masyarakat dengan prinsip-prinsip pendampingan dalam upaya pemberdayaan masyarakat yang meliputi :

1. Prinsip Spasial Lokal.

Penguasaan dan pemahaman terhadap ruang,kondisi, potensi dan bahasa lokal dalam pemberdayaan masyarakat.

2. Prinsip Berkelompok.

Kelompok tumbuh dari, oleh dan untuk kepentingan masyarakat. Selain dengan anggota kelompoknya sendiri, kerjasama juga dikembangkan antara kelompok dan mitra kerja lainnya agar usaha mereka berkembang, meningkatkan pendapatan dan kesejahteraan serta mampu membentuk kelembagaan ekonomi.

3. Prinsip Keberlanjutan

Seluruh kegiatan penumbuhan dan pengembangan diorientasikan pada terciptanya sistem dan mekanisme yang mendukung pemberdayaan masyarakat secara berkelanjutan. Berbagai kegiatan yang dilakukan merupakan kegiatan yang memiliki potensi berlanjut di kemudian hari.

4. Prinsip Kemandirian.

Masyarakat diberi motivasi dan dorongan untuk berusaha atas dasar kemauan dan kemampuan mereka sendiri dan tidak selalu tergantung pada bantuan dari luar.

5. Prinsip Kesatuan Keluarga.

Kepala keluarga beserta anggota keluarganya merupakan pemacu dan pemicu kemajuan usaha. Prinsip ini menuntut pendamping untuk memberdayakan seluruh anggota keluarga berperan serta dalam meningkatkan pendapatan dan kesejahteraan.

6. Prinsip Belajar Menemukan Sendiri.

Kelompok dalam masyarakat tumbuh dan berkembang atas dasar kemauan dan kemampuan mereka untuk belajar menemukan sendiri apa yang mereka butuhkan dan apa yang akan mereka kembangkan, termasuk upaya untuk mengubah penghidupan dan kehidupannya.

Pada prinsipnya pendampingan merupakan upaya untuk menyertakan masyarakat dalam mengembangkan berbagai potensi sehingga mampu mencapai kualitas kehidupan yang lebih baik. Selain itu diarahkan untuk memfasilitasi proses pengambilan keputusan yang terkait dengan kebutuhan masyarakat, membangun kemampuan dalam meningkatkan pendapatan, melaksanakan usaha yang berskala bisnis serta mengembangkan perencanaan dan pelaksanaan kegiatan partisipatif. Pendampingan dapat dipahami sebagai kegiatan dengan menempatkan tenaga pendamping sebagai fasilitator, komunikator, motivator dan dinamisator. 


\section{HASIL DAN PEMBAHASAN}

Pemberdayaan masyarakat di Desa Citemu pesisir pantai utara Kab Cirebon penting dikaji dalam upaya mengatasi persoalan kesejahteraan bagi masyarakat yang memiliki sumber daya laut yang melimpah tetapi tidak memiliki pekerjaan tetap, sehingga masyarakat pesisir pantai diharapkan dapat mengalami mobilitas vertikal, perlu formulasi konsep pemberdayaan yang muncul dari gagasan pemberdayaan dan pemahaman tentang karakteristik sosial masyarakat pesisir sebagai kelompok yang akan diberdayakan. Terdapat empat akses dalam pemberdayaan masyarakat pesisir berdasarkan pendapat (Satria, 2015) yaitu akses terhadap sumber daya alam, akses terhadap partisipasi, akses terhadap informasi dan pengetahuan adalah upaya menumbuhkan kapasitas dan kemampuan masyarakat untuk meningkatkan posisi tawar (bargaining position), sehingga memiliki akses dan kemampuan untuk mengambil keuntungan timbal balik dalam bidang sosial dan ekonomi.

Masyarakat desa Citemu menjadi yang obyek pengabdian masyarakat merespon dengan baik kedatangan tim pengabdian masyarakat untuk mendampingi mereka merintis usaha kerupuk rajungan dan bersedia menjalani program pemberdayaan masyarakat dengan sepakat melaksanakan prinsip-prinsip pemberdayaan sebagai berikut :

1. Melihat potensi berupa sumber daya alam hasil laut berupa rajungan

2. Membuat kelompok beranggotaan para perempuan yang bersedia bekerjasama merintis usaha

3. Menindaklanjuti kegiatan kelompok dengan usaha produksi kerupuk rajungan.

4. Kelompok diberi motivasi agar mampu berusaha secara mandiri

5. Usaha kerupuk sebagai usaha yang melibatkan anggota keluarga karena diproduksi di rumah dan dapat menghasilkan income generic

6. Produksi kerupuk dikerjakan dengan cara mencoba coba, beberapa kali gagal tidak memutuskan semangat untuk terus mencoba sampai dihasilkan kerupuk yang layak untuk diproduksi.

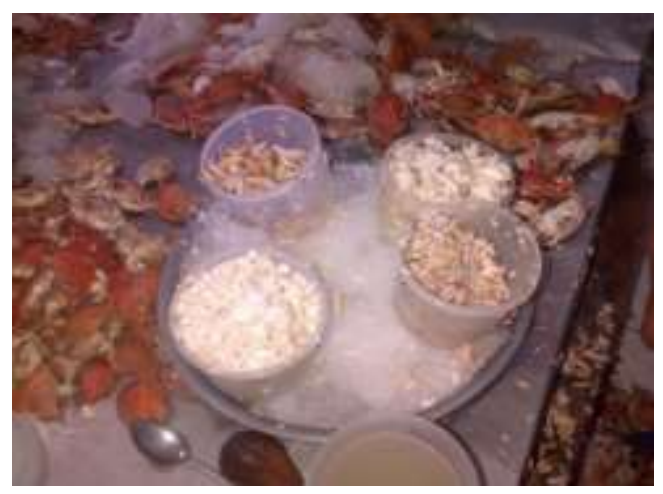

Foto : bahan baku

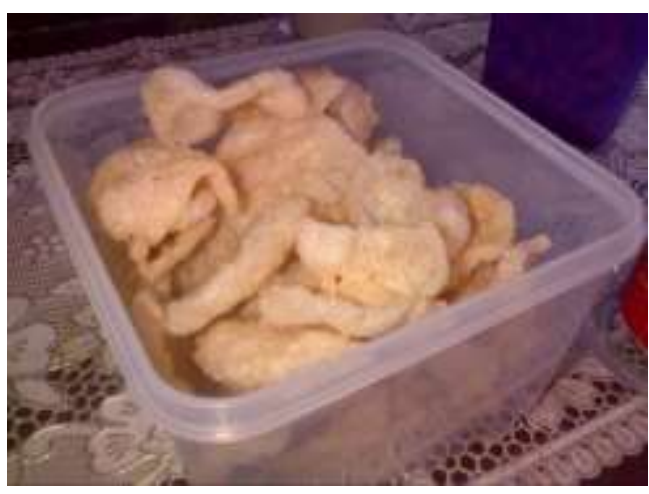

Foto : Kerupuk rajungan 


\section{Tahap-Tahap Pendampingan}

Dalam rangka mewujudkan program pemberdayaan masyarakat menjalankan usaha kelompok masyarakat Desa Citemu memproduksi kerupuk rajungan, maka Tim pengabdian masyarakat sebagai Pendamping di lapangan melaksanakan kegiatan pemberdayaan melalui 4 (empat) kegiatan penting sebagai kegiatan pemberdayaan masyarakat dengan menempatkan Tenaga Pendamping sebagai fasilitator, komunikator, motivator dan dinamisator yang secara langsung mendampingi masyarakat di lapangan melalui tahapan-tahap pendampingan sbb :

1. Fasilitator, (Peningkatan Kesadaran dan pelatihan kemampuan)

Pendamping menjembatani peningkatan kesadaran masyarakat melalui pendidikan keterampilan dasar dikembangkan melalui cara-cara partisipatif. Sementara pengetahuan lokal yang dimiliki masyarakat melalui pengalaman mereka dapat dikombinasikan dengan pengetahuan yang dari luar. Hal-hal seperti ini dapat membantu masyarakat menciptakan sumber penghidupan mereka sendiri dan membantu meningkatkan keterampilan dan keahlian mereka sendiri.

2. Komunikator (Manajemen diri)

Pendamping membangun komunikasi dengan masyarakat dimana setiap kelompok mampu memilih atau memiliki pemimpin yang nantinya dapat mengatur kegiatan mereka sendiri seperti melaksanakan pertemuan-pertemuan atau melakukan pencatatan dan pelaporan. Pada tahap awal, pendamping membantu mereka untuk mengembangkan sebuah sistem. Kemudian memberikan wewenang kepada mereka untuk melaksanakan dan mengatur sistem tersebut.

3. Motivator (Memberi Motivasi)

Masyarakat perlu didorong untuk membentuk kelompok agar mempermudah dalam hal pengorganisasian dan melaksanakan kegiatan pengembangan masyarakat. Kemudian Pendamping memotivasi mereka agar dapat terlibat dalam kegiatan pemberdayaan yang nantinya dapat meningkatkan pendapatan mereka dengan menggunakan kemampuan dan sumber daya yang mereka miliki.

4. Dinamisator (Pembangunan dan pengembangan jaringan)

Pengorganisasian kelompok-kelompok masyarakat perlu disertai dengan peningkatan kemampuan para anggotanya membangun dan mempertahankan jaringan dengan berbagai sistem sosial disekitarnya. Jaringan ini sangat penting dalam menyediakan dan mengembangkan berbagai akses terhadap sumber dan kesempatan bagi peningkatan keberdayaan masyarakat. 


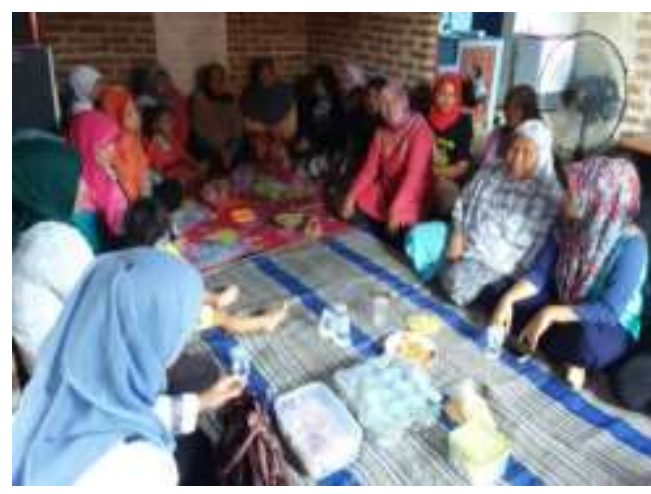

Foto : pembentukan kelompok

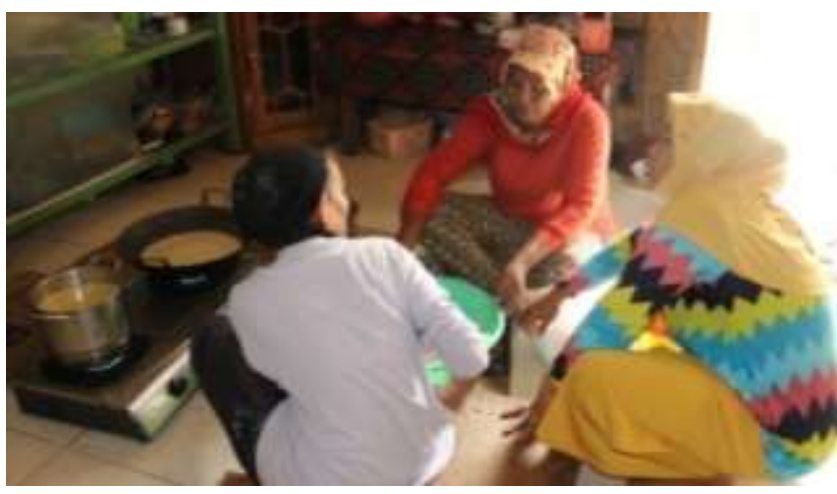

Foto : Praktek produksi

Pada dasarnya, pendampingan ini merupakan upaya untuk menyertakan masyarakat dalam mengembangkan berbagai potensi sehingga mampu mencapai kualitas kehidupan yang lebih baik, diarahkan untuk memfasilitasi:

1. Proses pengambilan keputusan yang terkait dengan kebutuhan masyarakat,

2. Membangun kemampuan dalam meningkatkan pendapatan,

3. Melaksanakan usaha yang berskala bisnis

4. Mengembangkan perencanaan dan pelaksanaan kegiatan partisipatif.

Kelompok masyarakat yang didampingi mampu mengembangkan potensi dalam diri mereka untuk melakukan kegiatan usaha yang produktif dan memperoleh penghasilan dari usaha kecilnya walaupun tidak sebesar skala bisnis karena keterbatasan modal.

\section{Peranan Dasar Pendamping}

Program pemberdayaan masyarakat di Desa Citemu menyadari bahwa ada hubungan tindak lanjut dari upaya memperbaiki kehidupan mayarakat untuk bisa bangkit dari kemiskinan membutuhkan kesadaran dari kelompok masyarakat yang dalam pelaksanaannya membutuhkan perhatian dari beberapa pihak, menurut (Ridwan M, 2012), berbagai teori telah menjelaskan hubungan kausalitas proses terjadinya kemiskinan dan mengapa pemberdayaan ekonomi masyarakat miskin harus dilakukan. Beberapa teori kemiskinan (teori lingkaran kemiskinan, teori budaya kemiskinan, dan beberapa teori kemiskinan lainnya) mengungkap penyebab kemiskinan baik dari faktor-faktor eksternal (seperti ketidak sempurnaan pasar, akses modal yang rendah, dan lain-lain) maupun faktor-faktor internal (seperti tingkat pendidikan yang rendah, tatanilai budaya, dan lain-lain).

Kelompok masyarakat yang telah terbentuk mulai menerima pendampingan yang membantu kesiapan usaha membuat kerupuk berbahan dasar rajungan. Pada dasarnya program pendampingan (Tenaga pendamping) melaksanakan 3 peranan : 
1. Penasehat Kelompok.

2. Pendamping berperan memberikan berbagai masukan dan pertimbangan yang diperlukan oleh kelompok dalam menghadapi masalah. Pendamping tidak memutuskan apa yang perlu dilakukan, akan tetapi kelompoklah yang nantinya membuat keputusan.

3. Trainer Participatoris.

4. Pendamping memiliki peran memberikan berbagai kemampuan dasar yang diperlukan oleh kelompok seperti mengelola rapat, pembukuan, administrasi, memecahkan masalah, mengambil keputusan dan sebagainya.

5. Link Person.

6. Pendamping berperan sebagai penghubung masyarakat dengan lembaga-lembaga yang terkait (stakeholder) dan diperlukan bagi pengembangan kelompok.

\section{Langkah Pemberdayaan Masyarakat}

Dalam proses pemberdayaan terhadap masyarakat di Desa Citemu telah melibatkan peran serta masyarakat agar dapat meningkatkan kesejahteraan sosial maupun ekonomi bagi kelompok masyarakat sesuai pendapat (Fahrudin, 2012) berikut; usaha kesejahteraan sosial harus melibatkan peran serta masyarakat agar dapat berhasil dan memberi manfaat kepada masyarakat. Oleh sebab itu, untuk dapat menciptakan kondisi kesejahteraan sosial dan kualitas hidup yang tinggi maka diperlukan penciptaan lingkungan yang mendukung, responsif dan memberdayakan individu dan masyarakat.

Namun pada pelakanaannya pemberdayaan berbasis kelompok ini tidak selalu berjalan dengan lancar, sejalan dengan Pendapat (Yonaldi, 2019) bahwa program pemberdayaan masyarakat miskin berbasis keluarga dalam aspek sosial, ekonomi dan lingkungan masih menghadapi beberapa masalah dalam pelaksanaannya. Permasalahan tersebut adalah kelembagaan kelompok belum terorganisir dengan baik, sehingga pengelolaan organisasi belum berjalan dengan semestinya.

Demi mengatasi permasalahan yang ada di lapangan, maka ditempuh langkah-langkah dalam melaksanakan solusi yang ditawarkan untuk membantu mengembangkan usaha kerupuk rajungan sebagai berikut:

1. Dalam bidang produksi

Pengolahan bahan baku kerupuk masih menggunakan alat tradisional dan pengerjaan yang sederhana. Mengaduk adonan (mengulen) dengan tangan yang belum tentu higienis. Proses penjemuran di tempat yang kurang layak. Pengemasan dengan plastik yang masih memakai tali rafia sebagai pengikat, atau dirapat dengan lilin. 


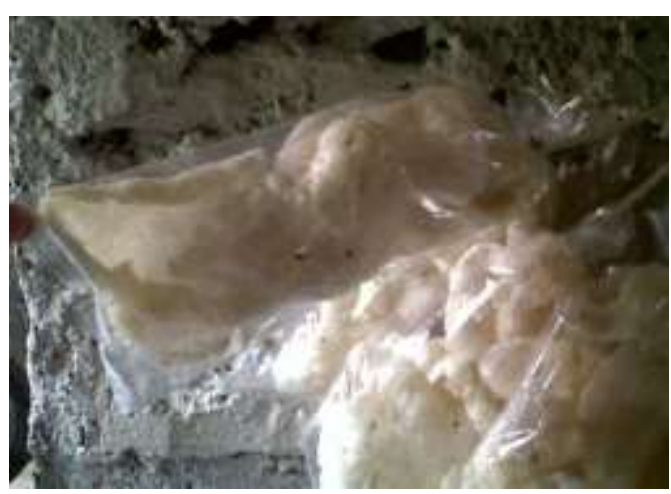

Foto : Kemasan kerupuk awal

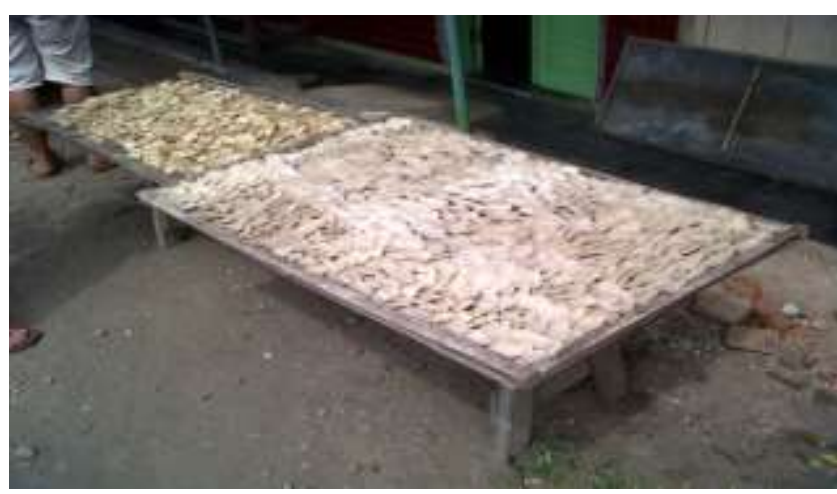

Foto : Proses penjemuran

2. Dalam Bidang Manajemen

Pendampingan dari Tim pengabdian masyarakat dibutuhkan oleh masyarakat pesisir pantai agar mampu memanaj produksi kerupuk sebagai produk yang dikelola secara terstruktur dengan pembagian tugas yang jelas bagi masing-masing pengrajin dalam kelompok tersebut. Hal ini dapat mengoptimalkan setiap kegiatan usaha kecil. Di mulai dari proses pengadaan bahan baku, pengolahan, pengemasan sampai pemasaran dan perhitungan harga pokok produksi, sehingga dapat memaksimalkan keuntungan bagi mitra. Sejalan dengan pemikiran (Adriyani, Widianti, Erna, \& Siswanto, 2018); Berdasarkan pengamatan fenomena permasalahan yang dihadapi, maka Desa Mundu Pesisir membutuhkan solusi yang efektif dan efisien. Menyangkut kondisi nyata di lapangan bahwa masyarakat bisa terbantu andaikata ada kegiatan usaha yang bisa menghasilkan penghasilan walaupun kecil tetapi berkelanjutan (income generik). Oleh karena itu, program Tatanan Ekonomi Masyarakat Nelayan (TEMAN) menjadi penting dilaksanakan demi memberikan konsep revitalisasi yang tepat agar masyarakat nelayan memiliki penghasilan tambahan. Upaya yang dilaksanakan adalah melalui manajemen usaha sederhana, tapi sangat bermanfaat bagi mereka. Dalam konteks ini, istri nelayan menjadi sasaran kegiatan karena berpotensi memberikan penghasilan tambahan sebagai income generik bagi keluarganya.

3. Dalam Bidang pemasaran

Proses peningkatan keterampilan terhadap masyarakat pesisir berusaha mengembangkan produk kerupukmemiliki nilai tambah, berusaha menciptakan produk dari daerah pesisir pantai sesuai keinginan konsumen bernilai kompetitif sehingga laku di pasaran. Strategi pemasaran yang ditawarkan oleh pendmping kepada mitra meliputi $4 \mathrm{P}$ yaitu ;

a. Produk : produk kerupuk rajungan masih dalam jumlah terbatas dan hanya tersedia di daerah Citemu, karena bahan baku tersedia di daerah tersebut sehingga jika dilakukan inovasi produk dapat memiliki nilai jual yang tinggi 
b. Price : selama ini kerupuk rajungan dikemas dalam bentuk sederhana dan kurang menarik sehingga berpengaruh terhadap harga jual yang murah, sehingga tidak terlalu berdampak terhadap peningkatan kesejahteraan masyarakat.

c. Place : untuk saat ini tempat menjual kerupuk hanya terbatas di warung dan pasar tradisional tertentu sehingga banyak yang belum mengenal produk tersebut.

d. Promotion : promosi yang dilakukan belum maksimal hanya di lingkungan terbatas dan belum memanfaatkan jaringan teknologi informasi.

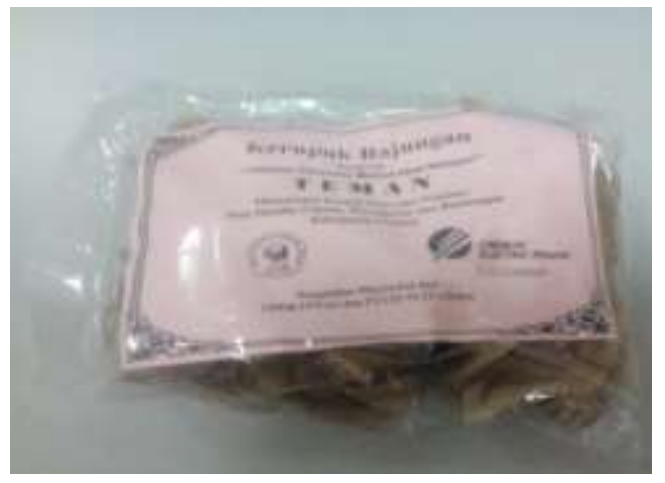

Foto : kemasan sederhana

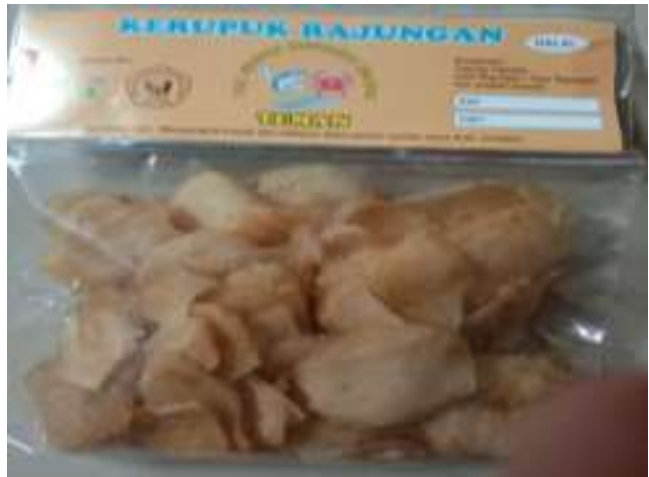

Foto : kemasan bermerk

Metode pendampingan ini mencoba menyelesaikan persoalan bagaimana membuat kerupuk rajungan menjadi komoditi yang berkualitas dalam jumlah /kuantitas yang memadai, maka diadakan hasil pemberdayaan masyarakat bisa memberi manfaat bagi mayarakat di Desa Citemu pesisir pantai. Upaya bersama telah berhasil meningkatkan kesejahteraan dengan cara memiliki usaha pembuatan kerupuk yang dirintis dalam kurun waktu satu tahun.

Adanya harapan terhadap upaya dari pihak-pihak yang peduli untuk membantu menanamkan kesadaran bersama meningkatkan kesejahteraan masyarakat pesisir pantai secara terorganisir dengan upaya tambahan berikut ini :

1. Penataan ekonomi yang berbasis kepada masyarakat nelayan agar masyarakat nelayan mampu memaksimalkan produk yang dihasilkan daerah setempat khususnya kerupuk sebagai usaha yang memiliki potensi besar laku di pasaran.

2. Masyarakat dengan terbuka menerima bantuan pendampingan berupa peningkatan keterampilan bagi pengembangan produk yang dihasilkanoleh kelompok binaan untuk meningkatkan nilai tambah produk kerupuk yang diolah kelompok perempuandidesa Citemu pesisir utara dalam rangka meningkatkan kesejahteraan masyarakat.

Dalam kurun waktu 12 bulan sudah nampak keberhasilan yang menggembirakan, bahwa kelompok mampu bekerja sama dalam menciptakan usaha produktif menambah penghasian keluarga sehingga berdampak positif terhadap perekonomian masyarakat dan kesejahteraan masyarakat. Tim pengabdian masyarakat telah berupaya memberikan bantuan teknis kepada 
kelompok dalam bentuk materil maupun non materil guna pengembangan lanjutan usaha para anggota, diantaranya memantau produksi kerupuk rajungan serta memberi bantuan peralatan untuk pengembangan usaha agar kualitas dan kuantitas kerupuk yang dihasilkan bisa terus meningkat.

Setelah berakhirnya masa pendampingan terhadap masyarakat Desa Citemu ini, tindaklanjutnya adalah menjaga agar program pemberdayaan yang telah dilaksanakan dapat memberi manfaat dan keberkahan bagi masyarakat di pesisir pantai utara khususnya Desa Citemu Kecamatan Mundu pesisir Kabupaten Cirebon.

\section{KESIMPULAN DAN SARAN}

Kesimpulan dari kegiatan pengabdian masyarakat di Desa Citemu ini adalah Program pemberdayaan masyarakat dapat terwujud apabila dilaksanakan bersamaan dengan pendampingan dengan metode yang sesuai situasi dan lingkungan lokasi Desa yang dijadikan obyek pengabdian masyarakat. Menciptakan usaha kecil berbasis kelompok pemberdayaan sebagai upaya dari pendampingan yang mampu mengembangkan dan mempromosikan produk kerupuk rajungan. Muncul hasil usaha kreatif berasal dari desa Citemu yang memiliki nilai jual dan menjadi sumber penghasilan tambahan income generic, sehingga diharapkan dapat mempengaruhi tingkat kesejahteraan masyarakat.

Selanjutnya disarankan agar tetap ada monitoring dan evaluasi kepada kelompok usaha tersebut agar program pemberdayaan masyarakat yang telah dilaksanakan bisa berlangsung secara berkesinambungan. Butuh peran serta pemerintah, industri, dan berbagai pihak terkait agar serius membina masyarakat terutama berorientasi peningkatan kesejahteraan. Harapan ke depan pemberdayaan kepada masyarakat ini bisa berlanjut pada tahap pengurusan PIRT dan label halal untuk produk kerupuk rajungan yang telah berhasil dirintis agar menambah nilai jual dan bisa ada peningkatan signifikan terhadap omset penjualan.

\section{UCAPAN TERIMA KASIH}

Ucapan terimakasih penulis sampaikan kepada:

- Kepala desa Citemu

- Hj Kuniah ketua kelompok usaha kerupuk

- Community Development Manager PT Cirebon Elektrik Power

\section{DAFTAR PUSTAKA}

Adriyani, R. (2019). Strategi Meningkatkan Nilai Produk Berbahan Mangga Melalui Pemberdayaan Masyarakat. DIMASJATI: Jurnal Pengabdian Kepada Masyarakat, 1(1), 81-93. 
Adriyani, R., Widianti, N., Erna, Er., \& Siswanto, A. (2018). Pemanfaatan Sisa Olahan Ikan dan Rajungan sebagai Income Generic bagi Masyarakat Mundu Pesisir Kabupaten Cirebon. In Strategi Inovasi Pengabdian Kepada Masyarakat Berbasis Kearifan Lokal (pp. 865-881). Bandung: FISIP UNPAS Press (Anggota IKAPI).

Albar, B. B., \& Yonaldi, S. (2013). Pemberian Pinjaman Bergulir Program Nasional Pemberdayaan Masyarakat Mandiri Perkotaan terhadap Kesejahteraan Masyarakat. Jurnal Manajemen Dan Kewirauahaan, 4(2), 1-9.

Dahuri, R., Irianto, B., \& Arovah, E. N. (2004). Budaya Bahari Sebuah Apresiasi di Cirebon. Jakarta: Perum Percetakan Negara RI.

Erna, E., \& Adriyani, R. (2019). Dampak Implementasi Kebijakan PUGAR Terhadap Kesejahteran Petani Garam di Pesisir Pantai Utara Kabupaten Cirebon. Jurnal Cendekia, $1(1), 25-45$.

Fahrudin, A. (2012). Pengantar Kesejahteraan Sosial. Bandung: Refika Aditama.

LPPM UNTAG Cirebon. (2015). Pogram TEMAN (Tatanan Ekonomi Mayarakat Nelayan) LPPM UNTAG bekerjasama dengan PT. Cirebon Elektric Power. Cirebon.

Mulyadi, N. (2009). Kewirausahaan \& Manajemen Usaha Kecil. Bandung: Alfabeta.

Phinisi, G. B. (2009). Pendampingan dalam Pemberdayaan Masyarakat (konsep, prinsip dan peranan).

Satria, A. (2015). Pengantar Sosiologi Masyarakat Pesisir. Jakarta: Pustaka Obor Indonesia.

Siswanti, A. D., Muadi, S., \& Chawa, A. F. (2016). Peran Pendampingan Dalam Program Pemberdayaan Masyarakat (Studi Pada Program Pendampingan Keluarga Balita Gizi Buruk di Kecamatan Semampir Kota Surabaya). WACANA: Jurnal Sosial Dan Humaniora, $19(3), 128-137$.

Sumodiningrat, G. (2009). Mewujudkan Kesejahteraan Bangsa: Menanggulangi Kemiskinan dengan Prinsip Pemberdayaan Masyarakat. Jakarta: PT. Alex Media Komputindo.

Yonaldi, S. (2019). Penguatan Kelembagaan, Administrasi dan Pelaporan Keuangan Pos Pemberdayaan Keluarga. Jurnal Pengabdian Kepada Masyarakat Dewantara, 2(2), 1116. 